\title{
The characterization of bacteriocins produced by Lactobacillus plantarum strains isolated from traditional fermented foods in Indonesia and the detection of its plantaricin-encoding genes
}

\author{
Sogandi ${ }^{1,}{ }^{*}$, Apon Zaenal Mustopa ${ }^{2}$, and I Made Artika ${ }^{3}$ \\ ${ }^{1}$ Faculty of Pharmacy, 17 Augustus 1945 University, Jakarta 14350, Indonesia \\ ${ }^{2}$ Research Center for Biotechnology-Indonesia Institute for Science (LIPI), Cibinong 16911 Bogor, Indonesia \\ ${ }^{3}$ Department of Biochemistry, Bogor Agricultural University, Bogor 16680, Indonesia \\ *Corresponding author: sogandi@uta45jakarta.ac.id
}

SUBMITTED 13 January 2019 REVISED 11 April 2019 ACCEPTED 23 May 2019

\begin{abstract}
Lactobacillus plantarum is widely found in either anaerobic plant matter or fermented foods, and it has been recognized as producing antimicrobial bacteriocins. This study aimed to characterize the antimicrobial bacteriocins of $L$. plantarum and detect its genes that encode plantaricins. Samples were isolated from traditional fermented foods from Indonesia. Antimicrobial activity was evaluated using the agar diffusion assay procedure. The titration method applied the maximum amounts of lactic acid at $1054 \mathrm{mg} / \mathrm{mL}$ and hydrogen peroxide at $3.85 \mathrm{mg} / \mathrm{mL}$. Based on the results, the supernatant of the $L$. plantarum strains appeared to have a broad spectrum of antimicrobial activity against pathogens, which would be active at pH 2.0-12.0 and stable temperature. In addition, almost all of the L. plantarum strains contained plantaricin-encoding genes (e.g. plnA, plnF, plnJK, and plnW), which were grouped into one cluster as indicated by phylogenetic analysis. Therefore, this study discovered clear evidence of the potential of some L. plantarum strains to act as antimicrobial agents.
\end{abstract}

KEYWORDS antimicrobial agent; bacteriocin; Lactobacillus plantarum; plantaricin genes

\section{Introduction}

Lactobacillus plantarum is classified as a lactic acid bacterium (LAB) group and Gram-positive bacteria that produces lactic acid as its main fermentation product into the culture medium. Generally recognized as safe (Konings et al. 2000), it is associated with many Indonesian traditional fermented foods such as bekasam (meat fermented food), tapai (fermented glutinous rice), and tempoyak (durian fermented food). These foods have been consumed for centuries, but no investigation has been conducted yet to assess the genes in LAB isolated from them. Bekasam was processed with mixing flesh with 10-20\% salt (w/v) and ground, roasted rice, then fermented (in sealed container) for 14 days. While tempoyak durian (Durio zibethinus) was made by mixing flesh with $2.5 \%$ salt (w/v) and placed in a sealed container to ferment for about 7 days. On the other hand, Tapai ketan was created by steaming ketan (glutinous rice) followed by inoculation with ragi tapai, then fermented for about 1-2 days until an acid-alcoholic taste was achieved (Mustopa 2014). These anaerobic bacteria play an essential role in extending the shelf life of fermented products and are known to produce antimicrobial substances such as organic acids, free fatty acids, hydrogen peroxide and bacteriocin which can inhibit the growth of several microbial (Mustopa 2014). Re- cently, various bacteriocin produced by L. plantarum isolated from fermented foods were investigated for their antimicrobial activity (Mustopa 2014; Xie et al. 2011).

Bacteriocins are ribosome-associated antimicrobial peptides as in a modified or unmodified state synthesized by Gram positive and Gram negative bacteria (Leroy and De Vuyst 2004; Xie et al. 2011). These small peptides have unique characteristics, such as (a) broad antimicrobial activity against the same species or across genera, (b) active peptides containing 20-60 amino acids, (c) specific receptors on the target cell, and (d) biosynthesis genes that involve plasmid (Drider et al. 2006). The bacteriocins produced by L. plantarum such as plantaricin A, E, F, J, and K belong to class II bacteriocin while plantaricin $\mathrm{W}$ is classified into class I of bacteriocin due to amino acid modification on it peptide (Kjos et al. 2009). In this study, a bacteriocin producing $L$. plantarum isolated from Indonesian fermented foods is identified and characterized, to determine its potential for various applications. Furthermore, the gene cluster encoding bacteriocin was determined.

\section{Materials and methods}

\subsection{Bacterial Strains and growth conditions}

Seven strains of L. plantarum were assayed for antimicrobial activity (Table 1). It was grown in MRS (De Man, 
Rogosa, \& Sharpe) broth (Oxoid) medium and incubated at $37^{\circ} \mathrm{C}$ for $20 \mathrm{~h}$ under anaerobic conditions according to the method proposed by Xie et al. (2011), with modifications. Bacterial strains used as indicators in this study and growth condition are shown in Table 1.

\subsection{Assay for antimicrobial activities of the lactic acid bacteria isolates}

Cell-free culture supernatants for antimicrobial assay was prepared by growing lactic acid bacteria (1\%, v/v) into 250 $\mathrm{mL}$ MRS medium at $37^{\circ} \mathrm{C}$ for $20 \mathrm{~h}$. The cells were harvested with centrifuged at $12.000 \mathrm{~g}, 4^{\circ} \mathrm{C}$ for $15 \mathrm{~min}$. The antimicrobial activity was determined by agar well diffusion assay. Microbial indicator were grown in a nutrient broth at $37^{\circ} \mathrm{C}$ overnight (Xie et al. 2011).

\subsection{Determination of lactic acid and hydrogen peroxide production by the LAB isolates}

Strain isolates of lactic acid bacteria were cultured in 100 $\mathrm{mL}$ MRS broth at $37^{\circ} \mathrm{C}$ temperature for $20 \mathrm{~h}$. Next, $25 \mathrm{~mL}$ of broth culture were added 3 drops of phenolphthalein as indicator. Meanwhile, $0.1 \mathrm{~N}$ sodium hydroxide was placed in to the burette, which them slowly added into the broth culture until its color changed to pink. In general, each milliliter of sodium hydroxide is equivalent to $90.80 \mathrm{mg}$ of lactic acid (Lelise et al. 2014). Then, $25 \mathrm{~mL}$ of diluted sulphuric acid was added into the $25 \mathrm{~mL}$ broth culture to determine its hydrogen peroxide content.

Titration was carried out with $0.1 \mathrm{~N}$ potassium permanganate up to decolourization occur. Each $1 \mathrm{~mL}$ of $0.1 \mathrm{~N}$ potassium permanganate is equivalent to $1.070 \mathrm{mg}$ of hydrogen peroxide. A decolorization for each sample was regraded as end point (Lelise et al. 2014).

\subsection{Sensitivity of bacteriocin to temperature, $\mathrm{pH}$, en- zymes, and surfactant}

All strains was grown in MRS medium for $20 \mathrm{~h}$ at $37^{\circ} \mathrm{C}$ and cell were harvested with centrifugated $12.000 \mathrm{~g}$ at $4^{\circ} \mathrm{C}$ for $15 \mathrm{~min}$. The effect of $\mathrm{pH}$ on the activity of plantaricin was tested by adjusting cell-free supernatants from $\mathrm{pH} 2.0$ to 12.0 (at increments of two $\mathrm{pH}$ units) with sterile $0.1 \mathrm{M}$ sodium hydroxide or $0.1 \mathrm{M}$ hydrochloric acid. After incubation for $2 \mathrm{~h}$ at $37^{\circ} \mathrm{C}$, all the samples $\mathrm{pH}$ were readjusted to $\mathrm{pH}$ 6.0. The effect of temperature on plantaricin activity was tested by incubating cell-free supernatants (adjusted to $\mathrm{pH} 6.0$ ) at $40^{\circ} \mathrm{C}, 60^{\circ} \mathrm{C}, 80^{\circ} \mathrm{C}$, and $100^{\circ} \mathrm{C}$ for 10,30 and 60 minutes respectively according to the method proposed by Teixeira et al. (2013) with modification.

Bacteriocin activity was also assayed after treatment at $121^{\circ} \mathrm{C}$ for $15 \mathrm{~min}$. Cell-free supernatant was incubated for $2 \mathrm{~h}$ in the presence of $1 \mathrm{mg} / \mathrm{mL}$ proteinase K (Invitrogen), catalase (Sigma), lyzosyme (Sigma), pepsin (Sigma), SDS (Biobasic), urea (Thermo), EDTA (Bio-rad, USA), PMSF (Sigma), and 1\% triton-x (MP Biomedicals). All antimicrobial activity was tested using the well-diffusion method (Teixeira et al. 2013).

\subsection{Isolation of genomic DNA and PCR conditions}

The total genomic DNA of L. plantarum strains was isolated in small scale, $5 \mathrm{~mL}$ culture in MRS broth (Oxoid) grown at $37^{\circ} \mathrm{C}$ overnight. Bacterial cells were collected by centrifugation at $6.000 \mathrm{~g}$ for $10 \mathrm{~min}$. The genomic or chromosome DNA was obtained according to the method of Zhu et al. (2013) with modification. The pellet was resuspended with $500 \mu \mathrm{L}$ TE buffer $(10 \mathrm{mM}$ Tris- $\mathrm{HCl} \mathrm{pH}$ $8.0,1 \mathrm{mM}$ EDTA) containing $60 \mathrm{mg} / \mathrm{mL}$ lysozyme and then incubated at $37^{\circ} \mathrm{C}$ for $1 \mathrm{~h}$. After incubation, $200 \mu \mathrm{L}$ of $10 \%$ sodium dodecyl sulfate, $100 \mu \mathrm{L}$ of $5 \mathrm{M}$ sodium chloride and $80 \mu \mathrm{L}$ of $10 \%$ CTAB were added. The mixture was then incubated at $68^{\circ} \mathrm{C}$ for $30 \mathrm{~min}$ and an equal amount of chloroform $(1: 1 \mathrm{v} / \mathrm{v})$ was added. Centrifugation was conducted at $13.000 \mathrm{~g}$ for $10 \mathrm{~min}$. The supernatant was collected and 1:1 (v/v) ethanol was added and then centrifuged at $13.000 \mathrm{~g}$ for $10 \mathrm{~min}$. DNA was dissolved in TE buffer containing $10 \mu \mathrm{g} / \mathrm{mL}$ RNAse (Zhu et al. 1993). Chromosomes DNA were used as templates to detect plan-

TABLE 1 Bacterial strains used in this study.

\begin{tabular}{|c|c|c|}
\hline Purpose for use and strains name & Source & Growth conditions \\
\hline Potential bacteriocin & Strains & Producing \\
\hline L. plantarum S12 & Bekasam (meat fermented food) & MRS broth at $37^{\circ} \mathrm{C}$ \\
\hline L. plantarum S14 & Bekasam (meat fermented food) & MRS broth at $37^{\circ} \mathrm{C}$ \\
\hline L. plantarum S31 & Bekasam (meat fermented food) & MRS broth at $37^{\circ} \mathrm{C}$ \\
\hline L. plantarum S34 & Bekasam (meat fermented food) & MRS broth at $37^{\circ} \mathrm{C}$ \\
\hline L. plantarum T3 & Tapai (fermented glutinous rice) & MRS broth at $37^{\circ} \mathrm{C}$ \\
\hline L. plantarum T8 & Tapai (fermented glutinous rice) & MRS broth at $37^{\circ} \mathrm{C}$ \\
\hline L. plantarum U10 & Tempoyak (durian fermented food) & MRS broth at $37^{\circ} \mathrm{C}$ \\
\hline \multicolumn{3}{|l|}{ Indicator strains } \\
\hline Bacillus subtilis ATCC 19659 & - & Nutrient broth at $37^{\circ} \mathrm{C}$ \\
\hline Salmonella typhi ATCC 25241 & - & Nutrient broth at $37^{\circ} \mathrm{C}$ \\
\hline Staphylococcus aureus ATCC 6538 & - & Nutrient broth at $37^{\circ} \mathrm{C}$ \\
\hline Pseudomonas aeruginosa ATCC15442 & - & Nutrient broth at $37^{\circ} \mathrm{C}$ \\
\hline
\end{tabular}


TABLE 2 Primers used for detection of genes plantaricin.

\begin{tabular}{llllll}
\hline $\begin{array}{l}\text { Target } \\
\text { gene }\end{array}$ & Forward primer (5'-3') & Reverse primer (5'-3') & $\mathrm{T}^{\dagger}$ & bp $^{\ddagger}$ & Reference \\
\hline plnA & ATTTCATGGTGATTCACGTTTAAATT & CTTACGCCATCTATACG & 54 & 300 & This study \\
plnEF & GGTGGTTTTAATCGGGGCGG & ACGGGGTTGTTGGGGGAGGC & 53 & 285 & Cho et al. (2010) \\
plnJk & ACGGGGTTGTTGGGGGAGGC & TTATAATCCCTTGAACCACC & 53 & 267 & Cho et al. (2010) \\
plnF & GACTGGATCCATGAAAAATTTCCTAGTTTT & GATCAAGCTTCTATCCGGATGAATCCTC & 58.5 & 159 & This study \\
plnW & GATCAGCCACGATACCAAC & CTAAAGAAAAAGCCCCTGAAAC & 58.5 & 750 & Sáenzet al. (2009) \\
plnAC & ATTTCATGGTGATTCACGTTTAAATT & AAATTGAACATATGGGTGCTTTAAATT & 55 & 2000 & This study \\
\hline
\end{tabular}

$\dagger$ Annealing temperature $\left({ }^{\circ} \mathrm{C}\right)$.

$\ddagger$ Amplicon size.

taricin genes with specific primers used to amplify genes in plantaricin locus showed in Table 2 . The PCR products were separated by electrophoresis using $1 \%(\mathrm{w} / \mathrm{v})$ agarose gel, which was stained with ethidium bromide and visualized using UV light source (Sukmarini et al. 2014).

\subsection{Amplification of plantaricin genes by PCR}

Plantaricin genes were amplified in $10 \mu \mathrm{L}$ volumes each containing $100 \mathrm{ng}$ template DNA, 1 unit/ $\mu \mathrm{L}$ Taq DNA polymerase $0.05 \mu \mathrm{L}, 10 \times$ buffer $1 \mu \mathrm{L}, 10 \mathrm{mM}$ dNTP 0.2 $\mu \mathrm{L}, 0.1 \mu \mathrm{L}$ forward primer, reverse primer, and their annealing temperatures in this study are listed in Table 2 . The PCR reaction were performed with an initial denaturation step at $94^{\circ} \mathrm{C}$ for $3 \mathrm{~min}$, followed by 35 cycles of $94^{\circ} \mathrm{C}$ for $30 \mathrm{~s}$, primer annealing temperature for $30 \mathrm{~s}$, and $72^{\circ} \mathrm{C}$ extension for $30 \mathrm{~s}$, followed by a final extension step at $72^{\circ} \mathrm{C}$ for $3 \mathrm{~min}$. PCR products were separated by electrophoresis using $1 \%(\mathrm{w} / \mathrm{v})$ agarose gel, which was stained with ethidium bromide and visualized using UV light source.

\subsection{DNA sequencing and phylogenetic analysis}

The PCR product was sequenced by 1st BASE company service. Similarity searches with sequences were performed by online BLAST analysis (http://blast.ncbi.nlm.gov/Blast.cgi). For phylogenetic analysis, sequences were aligned by using the CLUSTAL X Software (Thompson et al. 1997). A phylogenetic tree was constructed by the neighbor-joining method and the Streptococcus pyogenes strain was used as an outgroup. The stability of the relationship was assessed by bootstrap resampling. Bootstrap analysis was performed for 1000 trials in accordance to clustal X program (Saitou and Nei 1987).

\section{Results and discussion}

\subsection{Screening of potential antimicrobial lactic acid bac- teria}

The agar well-diffusion assay procedure was used to investigate the antimicrobial activity of seven lactic acid bacteria strains isolated from traditional fermented foods in Indonesia. Based on the results of this experiment, these isolates showed antimicrobial activity against at least bacterial indicators, which was presumed to be attributable as bacteriocin-like substances (BLS). The BLS were determined after $\mathrm{pH}$ level was neutralized to medium level and hydrogen peroxide was eliminated from the cell-free supernatants (CFS) (Anupama and Balasingh 2018). In general, almost all of tested LAB were able to kill Bacillus subtilis and Pseudomonas aeroginosa due to hydrogen peroxide present in medium, which is recognized as a strong oxidizing substance against organic matters. However, U10 isolate showed a broader antimicrobial activity spectrum against Salmonela typhi, Staphylococcus aureus, Bacillus subtilis and Pseudomonas aeroginosa due to BLS action. It appeared despite the remaining LAB also that showed similar results after a catalase treatment by using Bacillus subtilis and Pseudomonas aeroginosa as indicator pathogens. Therefore, this study presumed that various antimicrobial activities attributed to each strain appeared due to the production of bacteriocins or metabolites similar to them into medium as natural defences or an adaptive response to surrounding environment (Zhou et al. 2014). Antimicrobial activities of $L$. plantarum thus would be properly characterized by U10 strain isolate.

\subsection{Determination of lactic acid and hydrogen peroxide}

A heavy amount of lactic acid was produced during the 20-hour incubation, in which the highest amount was produced by S31 isolate (1054 mg/mL) compared to that of other isolates. On the other hand, the amount of hydrogen peroxide produced during the 20-hour incubation period was also recorded, by which T8 isolate was discovered to produce highest amount of hydrogen peroxide compared to other isolates.

The highest yield of lactic acid $(1054 \mathrm{mg} / \mathrm{mL})$ was produced by isolate S31 while the lowest yield of 720.64 $\mathrm{mg} / \mathrm{mL}$ was produced by isolate S34 and the highest yield of hydrogen peroxide was produced by isolate T8 $(3.85 \mathrm{mg} / \mathrm{mL})$ while isolate S34 produced the lowest yield $(2.35 \mathrm{mg} / \mathrm{mL})$. The increase in the production of lactic acid with time has been attributed to lowered $\mathrm{pH}$ which permit the growth of LAB. LAB can noted the inhibition of Bacillus subtilis, Salmonella typhi, Staphylococcus aureus, and Pseudomonas aeroginosa by hydrogen peroxide of LAB strains which contribute to their inhibitory activity against other microorganisms (González et al. 2015). 


\subsection{Characterization of the bacteriocin}

Plantaricin U10 was inhibitory against a variety of Grampositive and Gram-negative bacteria. Among the indicator species, the bacteriocin showed activity against Salmonella typhi, Staphylococcus aureus, Bacillus subtilis, and Pseudomonas aeroginosa. This result exhibit this BLS has a broad antibacterial activity. Even after treated at $121^{\circ} \mathrm{C}$ for 5 min (sterilization temperature) decrease antimicrobial from initial activity. This study clearly demonstrated that the BLS obtained from strain U10 is thermostable. Several studies have been reported that the BLS treated at $100^{\circ} \mathrm{C}$ for $60 \mathrm{~min}$ (Okpara et al. 2014) and $121^{\circ} \mathrm{C}$ for 15 min were stable at this high temperature (Zhou et al. 2014). This heat stability would be a very useful characteristic as antimicrobial peptide thermostable property in biomedicinal it could be used as antimicrobial peptide (Table 3). After incubation for $2 \mathrm{~h}$ at $\mathrm{pH}$ values from $\mathrm{pH}$ 2.0 to 8.0 stable activity but its activity slightly reduced at $\mathrm{pH} 10.00$ and showed activity at $\mathrm{pH} 12.0$ This result showed that the BLS was resistant to acid conditions (Table 4). That agreement with other research on characterized $L$. plantarum that inhibition zone $\mathrm{pH}$ treatment stable at range pH 2.0 to 8.0 (Jiang et al. 2017).

The results from enzyme inactivation studies exhibit that antimicrobial activity was lost or unstable after treatment with proteinase-k and pepsin, whereas treatment

TABLE 3 Effect of heat treatment on the antimicrobial activity of U10.

\begin{tabular}{|c|c|c|c|}
\hline \multirow[t]{2}{*}{ Application } & \multicolumn{3}{|c|}{ Activity antimicrobial } \\
\hline & $\begin{array}{l}\text { Salmonella } \\
\text { typhi }\end{array}$ & $\begin{array}{l}\text { Staphylococcus } \\
\text { aureus }\end{array}$ & $\begin{array}{l}\text { Escherichia } \\
\text { coli }\end{array}$ \\
\hline CFS* $^{*}$ & $+++^{1}$ & +++ & $\mathrm{nd}^{2}$ \\
\hline $\mathrm{BLS}^{* *}$ & +++ & +++ & nd \\
\hline $40^{\circ} \mathrm{C} / 10 \mathrm{~min}$ & +++ & +++ & +++ \\
\hline $40^{\circ} \mathrm{C} / 30 \mathrm{~min}$ & +++ & +++ & +++ \\
\hline $40^{\circ} \mathrm{C} / 60 \mathrm{~min}$ & +++ & +++ & +++ \\
\hline $60^{\circ} \mathrm{C} / 10 \mathrm{~min}$ & +++ & +++ & +++ \\
\hline $60^{\circ} \mathrm{C} / 30 \mathrm{~min}$ & +++ & +++ & +++ \\
\hline $60^{\circ} \mathrm{C} / 60 \mathrm{~min}$ & +++ & +++ & +++ \\
\hline $80^{\circ} \mathrm{C} / 10 \mathrm{~min}$ & +++ & +++ & +++ \\
\hline $80^{\circ} \mathrm{C} / 30 \mathrm{~min}$ & +++ & +++ & $++^{3}$ \\
\hline $80^{\circ} \mathrm{C} / 60 \mathrm{~min}$ & ++ & ++ & ++ \\
\hline $100^{\circ} \mathrm{C} / 10 \mathrm{~min}$ & ++ & ++ & +4 \\
\hline $100^{\circ} \mathrm{C} / 30 \mathrm{~min}$ & + & ++ & + \\
\hline $100^{\circ} \mathrm{C} / 60 \mathrm{~min}$ & + & + & -5 \\
\hline $121^{\circ} \mathrm{C} / 15 \mathrm{~min}$ & + & + & - \\
\hline
\end{tabular}

${ }^{1}$ Inhibitory zone $>10$.

2 Not determined.

3 Inhibitory zone $8-10 \mathrm{~mm}$.

${ }^{4}$ Inhibitory zone $5-7 \mathrm{~mm}$.

${ }^{5}$ No inhibitory zone.

${ }^{*}$ CFS: cell-free supernatant from LAB culture.

${ }^{* *} \mathrm{BLS}$ : CFC following the $\mathrm{pH}$ neutralization and hydrogen peroxide elimination. with catalase, lysozyme did not affect the activity of bacteriocin produced by U10. Furthermore, the antimicrobial activity of bacteriocins produced by U10 strain isolate appeared to not be affected by hydrogen peroxide or acidity, because the activity did not disappear after treatment with catalase/peroxidase or a pH adjustment to 6.0. In addition, non-ionic detergents such as Triton X-100 at a final concentration of $1 \%$ did not reveal any significant increase in bacteriocin activity (Table 4). In particular, Triton X-100 was discovered to not be capable of dissociating bacteriocin aggregate or no aggregate at all, causing significant disappearances of antimicrobial activity. However, the anionic detergent SDS increased in bacteriocin activity.

The increase in bacteriocin activity could be attributable to dispersion of the bacteriocin complex thereby releasing more unit for the activity. SDS itself an antibacterial agent thus increased bacteriocin activity shall be obtained (Holo et al. 2001).

\subsection{Determination of the genes encoding bacteriocin and phylogenetic relationship}

Six genes, which are present in the pln locus and are responsible for the synthesis of plantaricin, were searched

TABLE 4 Effect of enzymes, surfactant, and different $\mathrm{pH}$ treatment.

\begin{tabular}{|c|c|c|c|}
\hline \multirow[t]{2}{*}{ Application } & \multicolumn{3}{|c|}{ Activity antimicrobial } \\
\hline & $\begin{array}{l}\text { Salmonella } \\
\text { typhi }\end{array}$ & $\begin{array}{l}\text { Staphylococcus } \\
\text { aureus }\end{array}$ & $\begin{array}{l}\text { Escherichia } \\
\text { coli }\end{array}$ \\
\hline CFS & +++ & +++ & +++ \\
\hline BLS & +++ & +++ & +++ \\
\hline Precipitation & +++ & +++ & +++ \\
\hline \multicolumn{4}{|l|}{ Enzymes } \\
\hline $\begin{array}{l}\text { Proteinase-K } \\
\text { (Sigma) }\end{array}$ & - & - & - \\
\hline $\begin{array}{l}\text { Catalase } \\
\text { (Sigma) }\end{array}$ & +++ & +++ & +++ \\
\hline $\begin{array}{l}\text { Lyzosyme } \\
\text { (Sigma) }\end{array}$ & ++ & ++ & ++ \\
\hline $\begin{array}{l}\text { Pepsin } \\
\text { (Sigma) }\end{array}$ & + & + & + \\
\hline \multicolumn{4}{|l|}{ Surfactant } \\
\hline SDS & +++ & +++ & +++ \\
\hline Urea & ++ & ++ & ++ \\
\hline Triton-X & +++ & +++ & +++ \\
\hline EDTA & +++ & +++ & ++ \\
\hline PMSF & +++ & +++ & ++ \\
\hline \multicolumn{4}{|l|}{$\mathrm{pH}$} \\
\hline 2 & ++ & +++ & ++ \\
\hline 4 & +++ & +++ & +++ \\
\hline 6 & +++ & +++ & +++ \\
\hline 8 & ++ & ++ & ++ \\
\hline 10 & + & ++ & + \\
\hline 12 & + & + & + \\
\hline
\end{tabular}


TABLE 5 Strains used in this study.

\begin{tabular}{lcccccc}
\hline L. plantarum & PInA & PInABC & PInEF & PInF & plnJK & PInW \\
\hline S12 & + & - & - & - & - & - \\
S14 & + & + & - & - & - & - \\
S31 & + & - & + & + & + & + \\
S34 & + & - & + & + & + & + \\
T3 & + & - & - & - & + & - \\
T8 & + & - & - & - & + & - \\
U10 & + & - & - & + & + & + \\
\hline
\end{tabular}

+ Gene product present.

- Gene product absent.

in the L. plantarum strains. Table 5 summarizes the presence and absence of plantaricin genes in the strains of this study. The plnA gene was found in all strains. The presence of the plnA gene suggests that they belong to plantaritype group 1 and group 2, which share the common feature of the plnABC regulatory system (Rizzello et al. 2014). The plnABC and plnEF were only found in strains S14, S31, and S34, respectively, the plnF found in strains S34 and $\mathrm{U} 10$, and the sequence of region plantaricin $\mathrm{W}$ gene in class lantibiotic were found in three of the strains (S31, S34, and U10). Plantaricin W are relatively rare among bacteriocinogenic L. plantarum strains (Holo et al. 2001). Although highly conserved, the genes plnJK was variously detected in the L. plantarum strains S31, S34, T3, T8, and U10. These results are in agreement with other studies that have reported these genes as the most prevalent (Omar et al. 2008).

In an effort to identify the isolates at the species level, molecular phylogeny analysis was carried out and a phylogenetic tree was constructed based on the 16s rDNA sequence from evolutionary distance using the neighborjoining method. Although the $16 \mathrm{~s}$ rDNA sequence analysis method is very good at identifying the organism by genus and species, it cannot differentiate strains at the subspecies level and is therefore it is not the appropriate method for measuring intraspecies relationships (Stackebrandt and Goebel 1994).

The isolates of our collection were identified based on 16s rDNA gene amplification and sequencing using the universal primer. Analyses of a fragment of approximately 1465 bp (position 27-1492 in Escherechia coli), comprising the hypervariable regions of Lactobacillus, allowed the construction of the phylogenetic tree, which is shown in Figure 1.

The phylogenetic (neighbour-joining) tree showed the relationship between $L$. plantarum isolate in this study and another Lactobacillus base on aligned 16s rDNA sequence. BLAST search analysis using the whole 16s rDNA sequence resulted in identification above the 99\% level, although in two instances (U10 and S14) it was slightly lower. All homologies displayed were, however, above $97 \%$, which is considered to be the cutoff value indicating species identity (Stackebrandt and Goebel 1994).

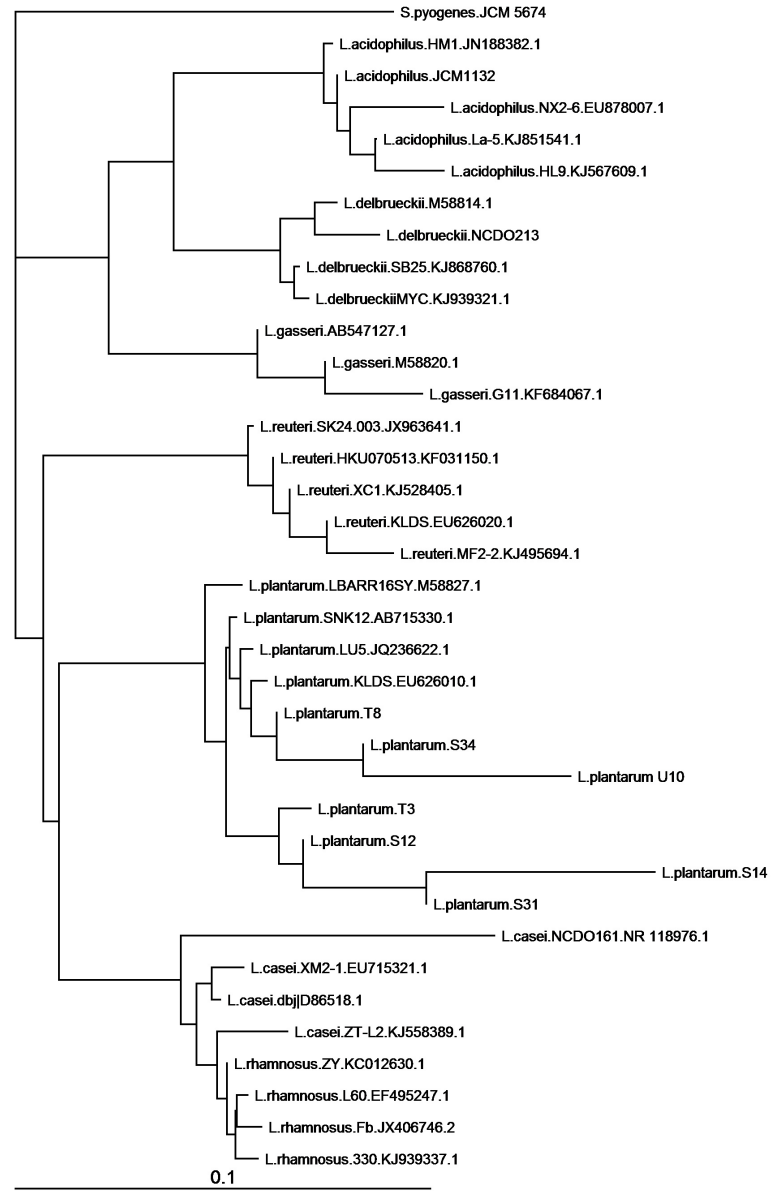

FIGURE 1 Phylogenetic tree showing the relative positions of lactic acid bacteria S12, S14, S31, S34, T3, T8, and U10 as inferred by the neighbor-joining method of complete 16s rDNA sequence. References of the type strains used for comparison are given, as well as the accession number for all 16s rDNA sequence. Streptococcus pyogenes is used as an outgroup. The horizontal branches are drawn proportionally to the number of nucleotide substitutions per site. The bar indicates $10 \%$ sequence divergence. L., Lactobacillus; S., Streptococcus.

\section{Conclusions}

In this study, the supernatant of L. plantarum strains under investigation showed a broad-spectrum of antimicrobial activity against pathogens. In fact, the activity appeared to have a heat-resistant characteristic and stable at a wide $\mathrm{pH}$ range. Besides, observed degradation of bacteriocins in the presence of proteolytic enzymes indicated its safety for being consumed by humans. Furthermore, almost all of $L$. plantarum strains under observation contained plantaricinencoding genes, which were grouped into one cluster as indicated by phylogenetic analysis. Therefore, this study concluded that some of $L$. plantarum strains isolated in this study offered their potential to act as antimicrobial agents.

\section{Acknowledgments}

The authors are grateful to Laboratory for Applied Genetic Engineering and Protein Design, Research Center for Biotechnology-LIPI Cibinong. 


\section{Authors' contributions}

AZM was designed this study. S carried out laboratory work and analyzed data. AZM and IMA advised about the laboratory technique and conducted manuscript proofreading before submission. All authors read and approved the final version of the manuscript.

\section{Competing interests}

The authors declare no other competing interests.

\section{References}

Anupama R, Balasingh A. 2018. Isolation, purification and characterisation of bacteriocin producing Lactobacillus species and its antimicrobial efficacy against food borne pathogens. Indian J Microbiol Res. 5(2):147-150. doi:10.18231/2394-5478.2018.0030.

Cho GS, Huch M, Hanak A, Holzapfel WH, Franz CM. 2010. Genetic analysis of the plantaricin EFI locus of Lactobacillus plantarum PCS20 reveals an unusual plantaricin $\mathrm{E}$ gene sequence as a result of mutation. Int J Food Microbiol. 141:117-124. doi:10.1016/j. ijfoodmicro.2010.02.022.

Drider D, Fimland G, Héchard Y, Lynn M. 2006. The continuing story of class IIa bacteriocins. Microbiol Mol Biol Rev. 70(2):564-582. doi:10.1128/MMBR. 00016-05.

González L, Cuadrillero AF, Castro JM, Bernardo A, Tornadijo ME. 2015. Selection of lactic acid bacteria isolated from San Simón da Costa cheese (PDO) in order to develop an autochthonous starter culture. Adv Microbiol. 5:748-759. doi:10.4236/aim.2015.51107.

Holo H, Jeknic Z, Daeschel M, Stevanovic S, Nes IF. 2001. Plantaricin W from Lactobacillus plantarum belongs to a new family of two-peptide lantibiotics. Microbiology. 147(3):643-651. doi:10.1099/ 00221287-147-3-643.

Jiang H, Zou J, Cheng H, Fang J, Huang G. 2017. Purification, characterization, and mode of action of pentocin JL-1, a novel bacteriocin isolated from Lactobacillus pentosus, against drug-resistant Staphylococcus aureus. Biomed Res Int. 2017:1-11. doi:10.1155/ 2017/7657190.

Kjos M, Nes IF, Diep DB. 2009. Class II one-peptide bacteriocins target a phylogenetically defined subgroup of mannose phosphotransferase systems on sensitive cells. Microbiology. 155(9):2949-2961. doi:10.1099/ mic.0.030015-0.

Konings WN, Kok J, Kuipers OP, Poolman B. 2000. Lactic acid bacteria: The bugs of the new millennium. Curr Opin Microbiol. 3(3):276-282. doi:10.1016/ S1369-5274(00)00089-8.

Lelise A, Belaynesh G, Mulubrhan M, Kedija S, Endashaw B, Abebe B. 2014. Isolation and screening of antibacterial producing lactic acid bacteria from traditionally fermented drinks ("Ergo" and "Tej”) in Gondar town, Northwest Ethiopia. Global Res J Public Health Epidemiol. 1(3):18-22.
Leroy F, De Vuyst L. 2004. Lactic acid bacteria as functional starter cultures for the food fermentation industry. Trends Food Sci Technol. 15(2):67-78. doi: 10.1016/j.tifs.2003.09.004.

Mustopa AZ. 2014. Diversity of lactic acid bacteria isolated from Indonesian traditional fermented foods. Microbiol Indones. 8(2):48-57. doi:10.5454/mi.8.2.2.

Okpara AN, Okolo BN, Ugwuanyi JO. 2014. Antimicrobial activities of lactic acid bacteria isolated from akamu and kunun-zaki (cereal based non-alcoholic beverages) in Nigeria. Afr J Biotechnol. 13(29):29772984. doi:10.5897/AJB12.376.

Omar B, Abriouel H, Keleke S, Sánchez A, Martínezcañamero M, Lucas R, Ortega E, Gálvez A. 2008. Bacteriocin-producing Lactobacillus strains isolated from poto poto, a Congolese fermented maize product, and genetic fingerprinting of their plantaricin operons. Int J Food Microbiol. 127(1-2):18-25. doi:10.1016/j. ijfoodmicro.2008.05.037.

Rizzello CG, Filannino P, Di Cagno R, Calasso M, Gobbetti M. 2014. Quorum-sensing regulation of constitutive plantaricin by Lactobacillus plantarum strains under a model system for vegetables and fruits. Appl Environ Microbiol. 80(2):777-787. doi:10.1128/AEM. 03224-13.

Sáenz Y, Rojo-Bezares B, Navarro L, Díez L, Somalo S, Zarazaga M, Ruiz-Larrea F, Torres C. 2009. Genetic diversity of the pln locus among oenological Lactobacillus plantarum strains. Int J Food Microbiol. 134(3):176-183. doi:10.1016/j.ijfoodmicro.2009.06. 004.

Saitou N, Nei M. 1987. The neighbor-joining method: a new method for reconstructing phylogenetic trees. Mol Biol Evol. 4(4):406-425. doi:10.1093/oxfordjournals.molbev.a040454.

Stackebrandt E, Goebel BM. 1994. Taxonomic note: a place for DNA-DNA reassociation and 16S rRNA sequence analysis in the present species definition in bacteriology. Int J Syst Evol Microbiol. 44(4):846-849. doi:10.1099/00207713-44-4-846.

Sukmarini L, Mustopa AZ, Normawati M, Muzdalifah I. 2014. Identification of antibiotic-resistance genes from lactic acid bacteria in indonesian fermented foods. HAYATI J Biosci. 21(3):144-150. doi:10. 4308/hjb.21.3.144.

Teixeira L, Rosa D, Brandelli A. 2013. Characterization of an antimicrobial peptide produced by Bacillus subtilis subsp. spizezinii showing inhibitory activity towards Haemophilus parasuis. Microbiology. 159(5):980988. doi:10.1099/mic.0.062828-0.

Thompson JD, Gibson TJ, Plewniak F, Jeanmougin F, Higgins DG. 1997. The CLUSTAL_X windows interface: flexible strategies for multiple sequence alignment aided by quality analysis tools. Nucleic Acids Res. 25(24):4876-4882. doi:10.1093/nar/25.24.4876.

Xie Y, An H, Hao Y, Qin Q, Huang Y, Luo Y, Zhang L. 2011. Characterization of an anti-Listeria bacteriocin produced by Lactobacillus plantarum LB-B1 isolated 
from koumiss, a traditionally fermented dairy product from China. Food Control. 22(7):1027-1031. doi:10. 1016/j.foodcont.2010.12.007.

Zhou F, Zhao H, Bai F, Dziugan P, Liu Y, Zhang B. 2014. Purification and characterisation of the bacteriocin produced by Lactobacillus plantarum, isolated from Chinese pickle. Czech J Food Sci. 32(5):430436. doi:10.17221/270/2013-CJFS.

Zhu H, Qu F, Zhu LH. 1993. Isolation of genomic DNAs from plants, fungi and bacteria using benzyl chloride. Nucleic Acids Res. 21(22):5279-5280. doi:10.1093/ nar/21.22.5279.

Zhu J, Adli M, Zou JY, Verstappen G, Coyne M, Zhang X, Durham T, Miri M, Deshpande V, De Jager PL, Bennett DA. 2013. Genome-wide chromatin state transitions associated with developmental and environmental cues. Cell. 152(3):642-654. doi:10.1016/j.cell. 2012.12.033. 